\title{
15 \\ Thwarted aspirations: The political economy of a Yolngu outstation, 1972 to the present
}

Frances Morphy and Howard Morphy

The outstation movement and the Aboriginal art movement have something in common: they are both often said to have originated, even to have been invented, at the beginning of the 1970s. Each is associated with myths of origin that privilege the agency of non-Indigenous actors. One is that the rise of contemporary Aboriginal art was initiated by a Papunya schoolteacher in 1971; another is that the outstations were an initiative of the Whitlam Government associated with land rights. Some have given H. C. ('Nugget') Coombs a primary role in influencing the direction of both: in the case of Papunya, the important contribution made by the Australia Council; in the case of the homelands, Coombs' romantic socialist imagination (Hughes 2007). Aesthetics and socialism come together in Helen Hughes' articulation of the primary motivations of those white intellectuals and public servants who supported the outstation movement: 'The homelands were designed to enable Aborigines and Torres Strait Islanders to enjoy their traditional lands as hunters and gatherers with culturally rich lives' (Hughes 2007: 5); and they were thought 'to have inherited communitarian social structures that were free of private property concepts' (p. 12). 
Myths of origin typically designate an originating moment or event, thus creating the very phenomenon they are trying to explain. They provide a uniformitarian perspective on events that may have a family resemblance but which arise from quite different historical trajectories and situational logics. In the case of the 'homelands movement', our argument will be that when we survey homelands or outstations in the north of Blue Mud Bay, in the Northern Territory, from the perspective of the longue durée we can see them as the outcome of a complex historical process of transformation that was influenced by a multiplicity of factors, both local and national in origin. There were factors that were particular to the circumstances of Yolngu people and that influenced the subsequent trajectory of the Yolngu homelands; these are factors that are commonly ignored, or that are, indeed, unknown at the non-local level, yet which need to be taken into account when planning for the future.

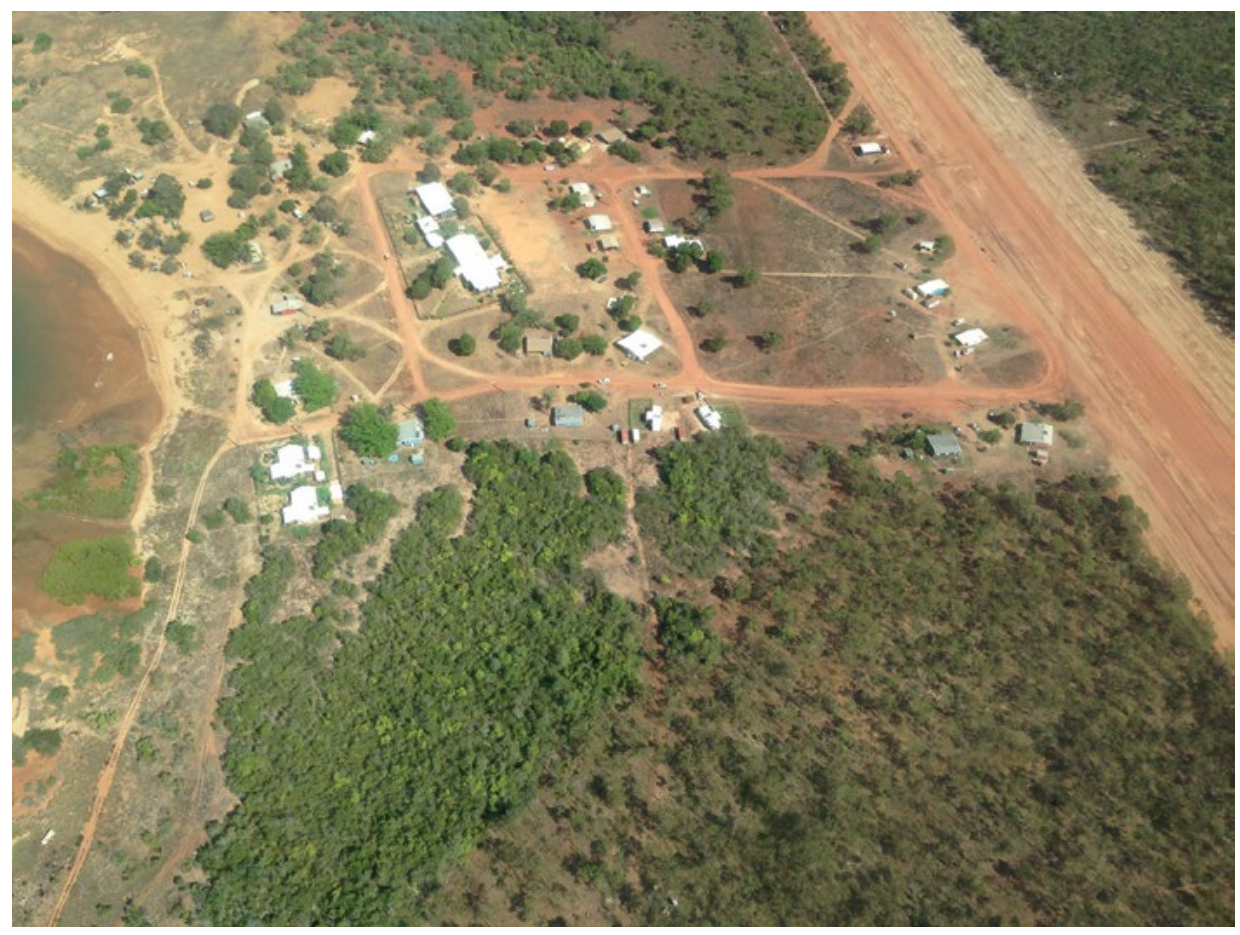

Figure 15.1 An aerial view of Yilpara.

Photo: Frances and Howard Morphy

We do not deny that the national initiatives introduced by the Whitlam Labor Government were a factor in facilitating the outstation movement - the move of Aboriginal people in many regions away from mission stations and government settlements to establish smaller communities on country (Coombs et al. 1980). And the prospect of land rights certainly provided one stimulus. However, in eastern Arnhem Land, it is possible to see the outstation movement 
as an outcome, in part, of the struggle for the recognition of rights and for relative autonomy, to position the movement as part of a continuing process of adjustment by Yolngu to the process of colonial encapsulation (Morphy and Morphy 2013). But to see the government initiatives as being the primary cause of the homelands movement is to deny Aboriginal inventions of the outstation movement in all their diversity.

In this chapter, we will argue that the development of outstations in eastern Arnhem Land allowed Yolngu to re-emplace a regional system of relationships (gurrutu) that had been disrupted in the early decades of the twentieth century as the region came increasingly under Australian Government control. While systems of alliance have changed over time, genealogical data confirm the Yolngu perception of the existence of enduring regional systems of marriage and affinity that link sets of clans together in connubial relationships. The establishment of government settlements and mission stations in the 1920s and 1930s created an externally imposed spatial framework for the relocation of the Yolngu population that was shaped by the pragmatics of the time.

Our primary case study focuses on a south-eastern Yolngu connubium, the Djalkiripuyngu, centred on the north of Blue Mud Bay, whose members had been dispersed among a number of different communities. This dispersal, and the fact that they were not the primary landowners in any of the communities to which they had moved, created long-term problems of adjustment. Regional alliances had always been shaped by external as well as internal relationships, and the outstation movement provided a context and an opportunity for the reconstitution of local political relationships that were perceived to be in continuity with past trajectories. Peterson has characterised the outstation movement as an example of an Indigenous life project, in which Indigenous people 'seek autonomy in deciding the meaning of their life independently of projects promoted by the state and the market' (2005: 7). The Djalkiripuyngu example is a clear case in point; however, such life projects cannot be pursued except in the context of articulation with state projects for Indigenous people, and state projects may either help or hinder. ${ }^{1}$

\footnotetext{
1 As Fred Myers has pointed out to us, the Yolngu case shares elements in common with outstation dynamics elsewhere in Australia in 'which people wanted to withdraw in order to re-establish some sort of political standing that was diminished by incorporation into another space' (personal communication). Myers' research on the Pintupi outstation of Yayayi shows how the Pintupi initially attempted to integrate themselves as 'one countrymen' within the population of the government settlement of Papunya before the tensions presented by the increased scale of social life became too great (Myers 1986: $40 \mathrm{ff} ., 257)$. The trajectories of the outstation movements, however, have been different in part because of the differences between Yolngu and Pintupi political structures (cf. Myers 1986: 295).
} 


\section{Yilpara in history}

The homeland settlement of Yilpara or Bäniyala has existed since 1972 as one of the initial outstations supported from Yirrkala mission. It has always had a large population. Mission records show that in 1974 there were about 70 people there, and in the 2000s there were periods when up to 170 people were regular residents. ${ }^{2}$ Yilpara is situated on a peninsula that juts out into the north of Blue Mud Bay (see Map 15.1). The settlement site was chosen in part because of its excellent permanent freshwater resources. Yilpara had always been a major, seasonally occupied settlement site. It is associated with a Yingapungapu burial ground and a restricted Ngärra performance space, both of which are of regional significance. However, the overall tenor of the surrounding land is garma, associated with more local ancestral forces: a good and safe place to camp. Yilpara is well resourced for living off the land and sea, with offshore reefs and seagrass beds, seasonal abundance of dugong and turtle, patches of vine thicket for yams and accessible wetlands and rivers.

Yilpara was also one of the sites of long-term trade with Macassans; nearby are the remains of a Macassan trepang-processing site. Oral history recounts the exchange of names between Wirrpanda, a senior member of one of the local clans, and a Macassan captain, 'Bäpa Basu' (quite possibly Pobasso, mentioned in Matthew Flinders' 1814 account of his 1803 visit to the east Arnhem Land coast) - an exchange that must have occurred in the late eighteenth or early nineteenth century. There is much evidence to show that Yilpara was, in geographical terms, a central node of the Djalkiripyungu, the connubium of Yolngu clans of the northern Blue Mud Bay region. ${ }^{3}$ And there is evidence that external trade relations with the Macassans resulted in Blue Mud Bay becoming a zone of connection and interaction, linking groups together around its perimeter. In particular, the southern Djalkiripuyngu clans developed very close relations, including intermarriage and trade, with the Anindilyakwaspeaking peoples of Groote and Bickerton islands. Yilpara was also a site of occasional interaction with the Europeans who serviced the Overland Telegraph and established cattle stations and mission stations in the Roper River region to the south.

\footnotetext{
2 These figures come from research in 2001 and 2006 on the national census in eastern Arnhem Land (F. Morphy 2002, 2007) and on subsequent as yet unpublished population research undertaken in the region in 2010 (see F. Morphy 2012).

3 This evidence was gathered by the authors in the course of the research for the Blue Mud Bay case (H. Morphy 2003), and is referenced in F. Morphy (2010).
} 


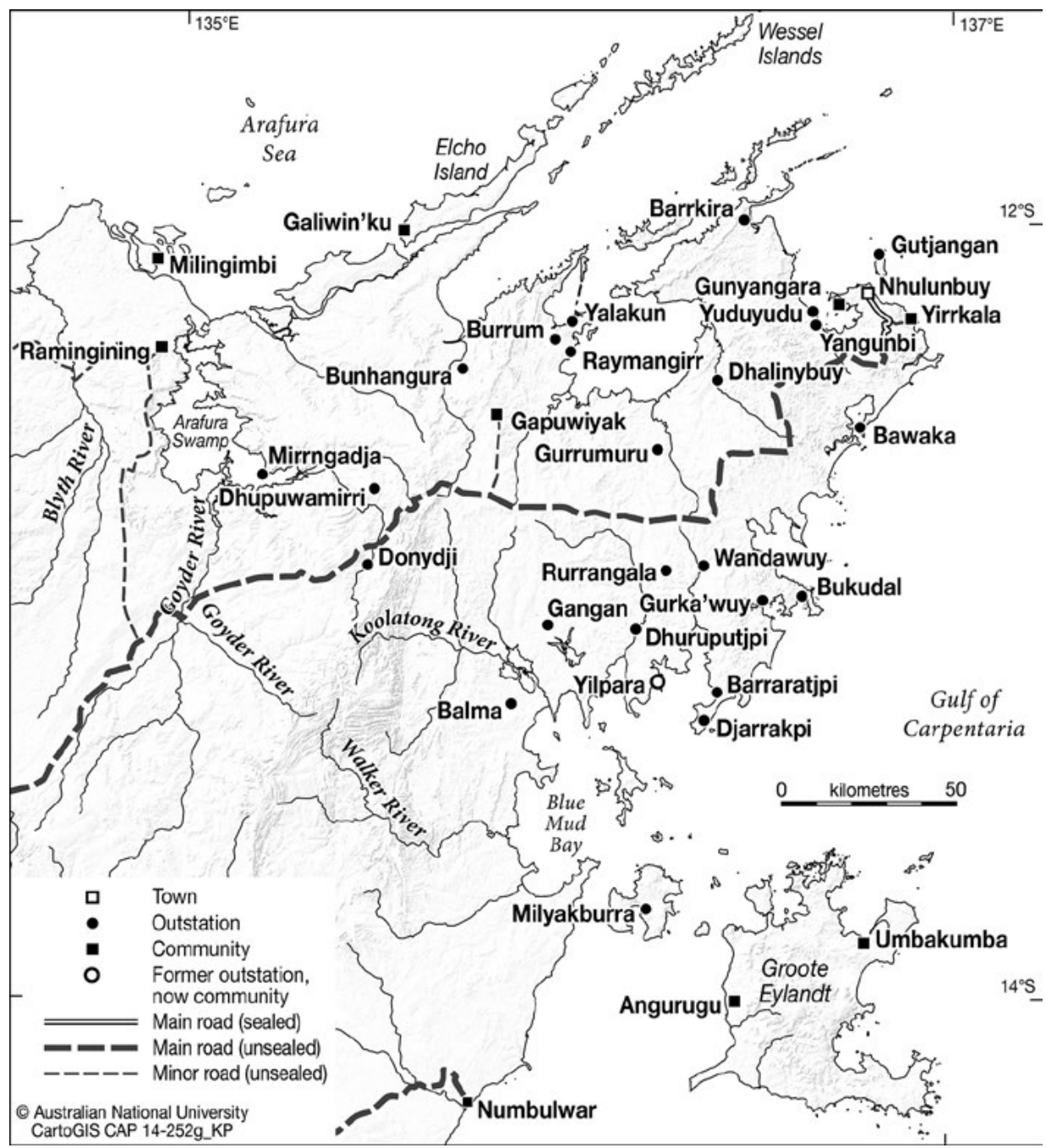

Map 15.1 Yilpara and the Laynhapuy homelands area, north-east Arnhem Land.

Source: Karina Pelling, CartoGIS, ANU College of Asia and the Pacific

This brief regional sketch provides a background to understanding the situation that developed after European colonisation. European intrusion into eastern Arnhem Land was a slow and at first intermittent process. It began with the visit of Flinders in early 1803, when Yolngu people had congregated at major coastal sites for turtle hunting and for the anticipated arrival of the Macassans. Flinders' crew had a violent encounter with Yolngu on Morgan Island in which one and possibly two Yolngu were killed. Over the next 130 years, Yolngu continued their trading relationships with outsiders, with the Macassans until 1907 and subsequently with Japanese and European visitors. European encroachment 
on Yolngu country took place on the western and southern boundaries with the development of cattle stations at the turn of the nineteenth and twentieth centuries. There were documented massacres in the region of the Arafura Swamp (see Dewar 1989) and another about 1911 at Gängan, within the Djalkiripuyngu region (Berndt and Berndt 1954: 101; H. Morphy 2003: 27).

These encroachments from the outside had an impact on Yolngu society internally. Some of the massacres were facilitated by Aboriginal people who were in effect clients of the Europeans at the advance of the frontier. Internal and external pressures came to a head in the early 1930s with the Caledon Bay killings. The crew of a Japanese pearling and trepanging vessel was killed in 1932, and in 1933 Constable McColl, one of the policemen sent out to investigate the deaths, was himself speared to death on Woodah Island (Egan 1996). The time of the Caledon Bay killings proved to be a watershed in the recent history of the region, which, from the present-day Yolngu perspective, brought an end to domains of conflict; it resulted in an end of conflict with Europeans through the process of missionisation and it greatly reduced the level of internal warfare. External evidence tends to support the Yolngu view of their history (see, for example, Clarke 2010: 22 ff.).

The establishment of the mission settlement of Yirrkala in 1935 was an element in a broader regional process of missionisation. However, Yirrkala's location on the far north-eastern corner of the Yolngu region also had consequential effects on the subsequent history of the region that are essential to understanding the distribution and composition of contemporary outstations of the eastern Yolngu area. Members of the Djalkiripuyngu clans made the decision to move a considerable distance from their clan lands centred on the Blue Mud Bay and Caledon Bay region. Some moved north to Yirrkala, and this entailed establishing stronger relationships with the clans of the northern coast, which was achieved in part by broadening the connections through marriage. In part because of the recent history of warfare, a number of Djalkiripuyngu never relocated permanently to Yirrkala and chose instead to move south to Numbulwar, Ngukurr (Roper River), Wugularr (Beswick) and Groote Eylandt.

\section{5-1970: 'Mission time’}

In the era between 1935 and 1970, Yolngu from Blue Mud Bay moved widely about the entire Yolngu region and beyond. People resident at the main settlements to the north and south maintained contact with their clan lands, going there for regular visits, trading crocodile skins with the missionaries, and travelling along the coast to meet up with relatives and participate in ceremonies (see Greenfield 1954a, 1954b). Some Yolngu remained permanently on country 
away from the settlements, and a number of semi-permanent settlements were developed across the Yolngu region, at Caledon Bay, Baykurrtji, Gurrumuru and Mirrngatja. ${ }^{4}$

Yolngu from the Djalkiripuyngu clans tried to get support from the Government and missions to establish their own settlements in the southern Yolngu area at Caledon and Blue Mud bays. In 1954 Brian Greenfield, a patrol officer for the Department of Native Affairs, noted a movement away from Yirrkala by people he refers to as the southern clans, including members of the Dhalwangu, Dhudi Djapu, Märi (Gupa) Djapu, Madarrpa, Munyuku, Manggalili and Marrakulu clans. Settlements had been established by Djeriny Mununggurr of the Gupa Djapu clan at Caledon Bay and by Mäw' Mununggurr at Trial Bay. Greenfield also refers to plans to establish a settlement in Manggalili clan country at Cape Shield (Djarrakpi). It is worth quoting from Greenfield's report as it provides a degree of evidence about Yolngu motivations at the time:

This reversion to their own tribal areas is evidence of many things, but mainly emphasises the original mistake of trying to mix two historically opposed factions [the north-eastern and south-eastern connubia: Laynhapuyngu and Djalkiripuyngu]. To my knowledge this is the first occasion that natives have quite without assistance, taken such decisive steps to regain a little of their independence that they originally sacrificed for the comforts and assistance of the mission welfare facilities.

They show no antagonism towards the mission itself. Their attitude to its endeavours is becoming cynical, but at the same time they are very much aware of the need of such an organisation for their ultimate development. The plans of these rebel groups is to place their children in the care of the mission to be schooled. When schooling is over, they will come back 'home' to help on the 'property', and carry on, peasant like in their fathers' footsteps. (Greenfield 1954b)

4 No histories of these settlements have been published. In a sense, they were continuing hunter-gatherer camps, occupied on a semi-permanent basis - sometimes unoccupied as people moved to other places and other settlements. Links with mission stations were facilitated by the building of airstrips, allowing regular visits from the missionary Harold Shepherdson, based at Elcho Island. Shepherdson was a missionary in Arnhem Land from 1927 to 1977 and began flying after he built his own plane in 1932. Ella Shepherdson's book, Half a Century in Arnhem Land (1981), provides an account of their lives in Arnhem Land. She writes that 'Baykurrtji a place on the Koolatong River was commenced in 1959. This was the ideal place for a garden because it had good soil and plenty of water. Our Fijian agriculturist, Penuia Sari, went down there and stayed for a fortnight to fence a garden and help the people plant sweet potato runners. They reaped the first crop but did not continue to plant, evidently preferring their own way of hunting in the bush. On one occasion at Baykurrtji, two women went washing clothes by the river when a crocodile caught one of them. She was never seen again. This upset the people of course, and they immediately moved camp to another place called Gängan. This place is still open and is contacted by the Yirrkala people' (Shepherdson 1981: 37). No date is given for the departure from Baykurrtji but when Nicolas Peterson visited the settlement in 1965, it had been reoccupied. Bandipandi Wunungmurra (personal communication, 2000) recalls the event. 


\section{Envisaging futures}

A number of themes recur in Yolngu visions of a future mode of existence adapted to the circumstances of colonisation. Some of these are reflected in Greenfield's report. The vision of a relatively autonomous existence for the homelands is clearly linked to the enterprises introduced by the missionaries and others who in their own interests had to create a local economy. The Methodist (later Uniting) Church had a strong ideology of making people work in return for rations. At Yirrkala the main economic activities involved the development of gardens to help make the community self-sufficient in food and the marketing of art and craft as a source of income. Most other enterprises, such as sawmilling and attempts to establish a fishing industry, were based primarily on a subsistence model. The people from Blue Mud Bay had a second source of inspiration when they worked for Fred Grey to establish the settlement of Umbakumba on Groote Eylandt. Grey's belief was that, free from the control of the missionaries, Yolngu would be able to establish small communities that were largely self-sufficient and develop a life independent of missionary or government. But his model for the economy was very similar to the mission's. And under the governance of the missionaries and Fred Grey, the major settlements of the region were moderately successful.

Yolngu also understood that another component was vital to sustain the kind of communities they envisaged: transport. The Djalkiripuyngu were in many respects people of the sea. Not only were they coastal hunters and gatherers, but also boats (principally dugout canoes) had provided a major mode of transport and opportunities for employment when working with the Macassans. The missionaries and Fred Grey, equally, built on this tradition; Yolngu worked on the mission lugger, which provided an essential mode of communication between settlements. Recurrent themes, in both Yolngu and missionary thinking, concerning what a settlement should comprise included: self-sufficiency in food and housing, schooling for the children and a ready means of transport. These are all themes that resonate still today in discussions of regional development. Matters of scale, which are still a factor today (as we shall see later), were sometimes invoked to characterise these aspirations as unrealistic. In response to Narritjin's requests for a barge to help found and supply a settlement at Djarrakpi, Greenfield was dismissive: 'Narritjin and another of his big ideas' (1954a). 


\section{Seizing opportunities}

The history of eastern Yolngu interaction with outsiders has been a combination of resistance to the impositions of the colonising society and the seizing of opportunities it provided. The early 1970s gave opportunities for both. Yolngu had been engaged over the previous decade in a struggle for land rights as a result of the granting of leases for bauxite mining on the Gove Peninsula near Yirrkala (see Williams 1986). The ultimate outcome of that struggle was not yet evident, for although they had lost the Gove land rights case, the incoming government had commissioned Justice Woodward to report on ways in which Aboriginal people in the Northern Territory could gain recognition of their title to land.

As we have seen, Yolngu people had, with some support from the mission, already begun attempts to move back on to country. Concern with what might happen to their land if they did not occupy it more permanently had now increased as a result of the Gove case. Conditions at Yirrkala mission were becoming more difficult with the development of the nearby mining town of Nhulunbuy and the opening of the Walkabout Hotel.

The advent of the Whitlam Government, with its support for the idea of selfdetermination for Aboriginal people, provided the opportunity to act decisively on the desire to move back to country; it did not create that desire. The new policy environment facilitated the establishment of small, dispersed communities while increasing support from the Uniting Church, which had been actively supportive of the Yolngu in the Gove case, allowed the maintenance of links with and support from the settlement at Yirrkala.

A number of other factors must also be taken into account. The development of the mining town of Nhulunbuy had marginally improved regional transport infrastructure, and the Methodist Aviation Fellowship began to provide efficient and relatively low-cost air transport. Toyota four-wheel-drive vehicles provided the land equivalent of the dugout canoe for travelling between settlements, and indeed in the Yolngu case Toyotas received names previously reserved for canoes. The mission provided each outstation with minimal resources in the form of sheet iron for housing, water pumps and access to equipment such as graders. Some government subventions began to flow, but on the whole the outstations were built with minimal resources. The airstrips were laboriously cleared by hand and houses built by members of the community trained in basic construction methods by the missionaries and using local timber. The initial economy was based on hunting and gathering of food and art and craft production, supplemented by welfare payments that had recently begun 
to be a significant input into the region. Quite early on education followed the establishment of the outstations and Yolngu teachers' and teaching assistants' salaries began to make an additional contribution.

The establishment of the outstations did not simply involve a movement of people away from Yirrkala. Members of Djalkiripuyngu clans, such as the Madarrpa, Dhui Djapu, Munyuku and Dhäpuyngu, who had for various reasons not wanted to move to Yirrkala mission, took the opportunity to join those moving from Yirrkala back to their country. To a considerable extent, this enabled the regrouping of the Djalkiripuyngu connubium, whose interactions had been disrupted by people's dispersal to settlements in distant places.

\section{Yilpara is established}

Yilpara was among the first of the Yolngu outstations to be established, on Madarrpa country. The initial population was built on a set of core individuals of the Madarrpa, Munyuku, Dhäpuyngu and Dhudi Djapu clans - all clans of the northern Blue Mud Bay Djalkiripuyngu connubium. Not all intended to remain there permanently but rather to use Yilpara as the springboard for establishing their own homelands in neighbouring places. In subsequent years, further outstations were built nearby, at Rurrangala on Munyuku country and at Dhuruputjpi on Dhudi Djapu country. Together with Gängan, Djarrakpi and Wandawuy, which were established at the same time as Yilpara, these form an interconnected set of settlements with shared histories that long predate the homelands movement itself - a region within a region. Over time at Yilpara, the Madarrpa were joined by some members of other clans from the connubium, particularly Gupa Djapu and Marrakulu-clans of the opposite moiety. Many Madarrpa have Marrakulu mothers, and many Djapu have Madarrpa mothers.

Ian Dunlop's film We are the Landowner (filmed in 1982; released in 1985) provides an excellent record of aspects of life in Yilpara during its formative period and illustrates the aspirations of some of its leaders. Djambawa Marawili and Gumbaniya Marawili emphasised their long-term connection to the country. They took Ian to the area of jungle behind the settlement:

We can see this tree, wangupini, our grandfather planted it - a tree he brought from Barratjala - and it reminds us of his presence in this country. This is the old people's land and this is why we have come here to live ... I am here in my own land and I am moving around in my own area-I know how ... and where to walk - we have got everything here, no reason to go back to Yirrkala. (Dunlop 1985) 
And virtually everything at that time had been built by the people who lived there. At the heart of the outstation was the school, housed in a tin shed, which began with more than 30 students, from infant to post-primary, divided into three classes. The school was established initially as an outpost of the Yirrkala School, with additional support provided by the Isolated Students Allowance (ISA). The senior teacher was Galuma Maymuru (Djambawa's mother-in-law to be), who had previously been a teaching assistant at Yirrkala. The available educational funding covered the costs of two teachers, with a third paid out of the ISA monies. This was Galuma's idea, and she also started a canteen to provide children's lunches, funded by the parents. Her ambition was to make a profit to plough back into the school budget to acquire a school vehicle. The school was an English-language school since it was felt that the children gained sufficient education in their own language and culture outside school hours. This has continued to be the policy applied to homeland schools since that time. The main non-benefit income apart from the teachers' salaries was derived from art and craft production. In the years immediately after the establishment of the homelands, the income from the sale of craft through Yirrkala increased tenfold, with most of the production coming from the outstations.

In the years since its establishment in 1972, Yilpara has maintained a sizeable population of more than 100 individuals, with considerably more present at ceremonial times. Over time the infrastructure of the community has developed slowly. Bore water is sourced via a solar and wind generator pump and, since 2006, electricity has been generated by a substantial diesel-powered generator that is able to supply the entire community. But it is costly to run. Housing improved greatly in the 1990s, with more substantial houses being built under the auspices of the Laynhapuy Homelands Association, the local outstation resource centre, on the footprints of the original outstation buildings. Schooling came under the management of the Yirrkala-based homelands school, and a new school was built. The teaching system used a combination of locally resident teaching assistants and visiting (mostly non-Yolngu) teachers from the Yirrkala base, who stayed in the community for three days a week. The community also gained a small building to house the office and the clinic. Yilpara has a small store, the fortunes of which have waxed and waned; it is now operated as an IGA. ${ }^{5}$ The economy was built around welfare payments, salaries of teaching assistants and health workers and subsidised employment facilitated by community development schemes of which the most important was Community Development Employment Projects (CDEP). The last enabled the provision of local services such as refuse collection and community grounds maintenance. Hunting and gathering and art production continued to be important nonsubsidised sources of income and subsistence. Yirrkala outstations continued to 
be the main source of production for what became Buku Larrnggay Mulka art centre. The art centre developed in the decades after the 1970s into a considerable business in which the return from art alone brought in an annual income of more than $\$ 2$ million, most of which was generated by the southern homelands. The art centre also became one of the main conduits for communication and interaction with the wider Australian community and resulted in some Yilpara community members having regional and national roles.

Linkage within the broader economic framework was also facilitated by the development of a regional ranger program covering the Laynhapuy homelands. The Yirralka ranger program was instituted in 2003 and the later declaration of the Laynhapuy Indigenous Protected Area (IPA) created further opportunities for employment for both men and women. People from Yilpara had been leading players in the establishment of the ranger group and the IPA, which came in part out of the work they undertook for the Blue Mud Bay native title claim. The Yolngu view the establishment of the IPA as being in continuity with the struggle for land and sea rights and the homelands movement, reflecting the need to occupy and protect country. As Waka Mununggurr put it:

I am the child of this country, its manager and caretaker. I care for the land and the laws of this Madarrpa clan, for their sea and their land. Yes, it was for this that we established the Rangers. We wanted to have them care for the country, the sea and the inland together. Yes, this was needed because we have seen some bad things happen here before. [Professional] fishermen despoiled this country, they came in ignorantly ... Then we provided evidence [to the Blue Mud Bay court hearing]. Because of this, we then wanted a Ranger program. The Rangers will patrol and monitor the boundaries in the sea and care for the land. This is the reason why we undertook that sea rights claim. (Translation from the original in Yolngu matha, cited in LHAI 2006: 6, 9)

The past decade has also seen the slow emergence of cultural tourism as a possible industry, with a number of initiatives now in place.

\section{Thwarted aspirations: Recurring themes}

Measured in terms of the stability of their population, the Yirrkala homelands, including Yilpara, have been successful communities. Today they comprise about 50 per cent of the regional population, and there is no evidence of 
population decline. ${ }^{6}$ However, there has been a long history of dissatisfaction with the way the homelands have been treated and the people of Yilpara have led much of the critique. The main criticisms have centred on housing, schooling and employment opportunities.

We returned to work at Yilpara in 1997, using it as our base for research for the Blue Mud Bay case. The concerns displayed then by the community have remained essentially unchanged and until recently have been largely unaddressed. In the case of housing, the resources available from government for homelands became scarcer and the cost of housing increased exponentially. Government funding for new homelands community housing ceased altogether in 2008. Over the years, the Government's model of housing delivery had resulted in building regulations and tendering processes that had the effect of taking construction out of the hands of Yolngu. In the period from 1997 to 2007, not a single house was built to address the significant overcrowding in the community. Moreover, limited resources were available for other community facilities, including spaces for art production, visitor accommodation and tourism development. The Laynhapuy Homelands Association (LHA), established in 1985 to service the homelands, had limited resources to satisfy the demand, and regulatory structures meant it was difficult for them to provide cheaper solutions using government funding.

With schooling, the desire for full-time residential teachers in an enlarged school premises to match the increasing school-age population was also slow to be satisfied. It required changes in the policy of the homeland school; creating different models for different outstations was both ideologically and logistically difficult.

The economic development of outstations had never been a government priority, and again limited resources were available. LHA's main function was as a resource centre supporting the infrastructure needs of the homelands; economic development was a secondary concern, inadequately resourced and funded. The main resource that was available for LHA to manage in this area was the CDEP program. CDEP was designed to help support and generate employment in remote areas but, beginning in the time of the Howard Coalition

6 This figure is derived from as yet unpublished research by Frances Morphy, who conducted a regional population survey in 2010. The survey covered Yirrkala and Gapuwiyak, and all the homelands serviced from those major communities. The figure of 50 per cent relates to the community of Yirrkala and the set of homelands originally serviced from Yirrkala by the Laynhapuy Homelands Association (LHA) (now Laynhapuy Homelands Aboriginal Corporation). In the late 2000s, LHA assumed responsibility for servicing a group of homelands that had previously been serviced from Gapuwiyak. For this larger region as a whole, the homelands population comprises one-third of the population. 
Government, it was increasingly subject to ideologically motivated criticism. ${ }^{7}$ Organisations like LHA, which managed CDEP programs, increasingly spent much of their time defending an uncertain resource, rather than deploying the energy necessary to make it work more effectively in achieving the objectives for which it was set up. ${ }^{8}$

The rhetoric from government that emphasised the creation of 'real' jobs had considerable purchase within the Yilpara community, yet there was little understanding (in the community or indeed in governments and the local bureaucracy) of where those jobs would come from. Indeed, in many respects, government policy (of all complexions) in the spheres of both employment and housing was increasingly directed towards moving people away from the homelands to the hub settlements, rather than providing solutions where people lived.

At Yilpara, it was a case of 'shoot the messenger'. The community leaders became increasingly disillusioned with and even hostile to the LHA. For its part, LHA, in attempting to fulfil a development role, overextended itself financially. It has only just recently emerged from a period of special administration under the new title of the Laynhapuy Homelands Aboriginal Corporation (LHAC).

\section{Pragmatic Yilpara: Seizing opportunities again}

Recent developments at Yilpara have involved a complex relationship between community demands and the response of a number of competing non-Indigenous organisations and interests operating in the public and private or voluntary sectors. Developments in the areas of infrastructure, education and housing can be only briefly summarised here.

The involvement of the Centre for Independent Studies (CIS) and Sydney Cove Rotary Club began in early 2000. The Rotary Club responded to requests from the community to build facilities, successfully bidding for contracts to undertake work and providing skilled volunteer labour. They worked with local Yolngu labour, also voluntary, to build an artists' studio and a women's cultural centre, and subsequently built a visiting officers' quarters (VOQ), comprising a kitchen, two bedrooms for visitors and a lecture theatre/dining room. The Rotary volunteers also worked with Yolngu to construct a permanent campsite for guests

7 The saga of the demise of CDEP is a topic in itself. For the beginning of the end, see Peter Shergold's (2001) contribution to a volume dedicated to an evaluation of CDEP (Morphy and Sanders 2001). At the time, Shergold was the secretary of the Commonwealth Department of Employment, Workplace Relations and Small Business.

8 For an analysis of the governance of LHA in the mid 2000s, and the tensions generated by serving two masters - the Yolngu residents of the homelands and government paymasters - see F. Morphy (2008). 
taking part in a planned future program of cultural and environmental tourism. The concept for the latter had been developed by Stepwise, a consultancy organisation with loose connections to The Australian National University. The VOQ has served a number of different purposes, providing accommodation for visiting researchers, leaders of tour groups and volunteers. Latterly, it served as accommodation for the manager of the Yilpara store after it had been taken over by the Nhulunbuy IGA. It is also used as a training centre, for Laynhapuywide training courses as well as purely local training.

Members of the Yilpara community had long been demanding that the NT Education Department provide a school staffed by full-time teachers resident in the settlement. They also wanted the school buildings to be upgraded to provide more classrooms and better facilities. Yolngu faced two main problems in pursuing these demands. They required the school to be set up on a different basis from other homeland schools and they required that a larger budget be allocated to cover the costs of resident teachers. Their case had a strong national political dimension to it since it was strongly supported by researchers associated with the CIS, whose discourse involved a critique of bilingual education (despite the fact that Yilpara school was not a bilingual school), of government schools and of the ideological basis of public education. The Education Department, after many years of discussion and lobbying, agreed to fund a school for Yilpara that fitted in with Yolngu wishes. The building of a new school was funded by the department, as was the construction of two houses for the resident teachers. Although Yolngu and others often refer to the new school as 'independent', it is run by the NT Department of Education. Its curriculum is similar to those of other government schools and, as is the case with other homeland schools, it is not bilingual. Its difference from other Yolngu outstation schools is that it has been set up as an autonomous local 'small school' and does not come under the umbrella of the Yirrkala Homeland School.

The houses for the teachers were the first to be built at Yilpara in more than a decade and highlighted the community's overall housing problem. Indeed, changes in government policy in recent years have made it impossible for local organisations such as LHA (now LHAC) to be able to build new houses in homelands. This has opened up the opportunity for the rhetoric of private home-ownership as a solution to Indigenous housing problems to gain some purchase. Yilpara (aided by CIS) petitioned the Federal Government and the Northern Land Council (NLC) for the granting of 99-year leases to individuals in order that they can become owners of (or, rather, take out mortgages for) private dwellings. The NLC did not respond positively. Yilpara (via their CIS/Rotary advisers) enlisted the aid of the Australian Indigenous Chamber of Commerce (AICC), whose executive chairman is Warren Mundine. The following appears on the AICC website: 
In 2012 the ICBF [Indigenous Community Benevolent Fund] arranged for two transportable and fully furnished and equipped homes to be transported and installed at Yilpara. These homes cost $\$ 150,000$ each, ready to move in (as compared to Government-built houses on remote communities which cost about $\$ 450,000$ or more). The homes are being leased back to two Yilpara families and are intended to be sold to them if and when 99-year leases are implemented.

The Chamber saw first hand these two homes in Yilpara. Nearly a year old they now have pretty gardens out the front and are obviously well cared for. ${ }^{9}$

The issue of continuing repairs and long-term infrastructure support for the houses has yet to be finally negotiated with LHAC, which continues to have the main responsibility for homeland support. We do not have space here to fully describe the complex networks of influence that led to this interim solution to the Yilpara housing problem.

It is deeply ironic that the ideological critique of the outstation movement associated with neoliberal organisations, in particular the CIS, had one of its bases in the community of Yilpara itself. The irony is that the CIS, while critiquing homelands as a form of apartheid (Hughes 2007), simultaneously provided the opportunities for Yilpara to increase its resources locally and remain relatively autonomous of the hub communities. The support of the CIS and the Sydney Cove Rotary Club also enabled the community to remain on a trajectory that utilised the value of its cultural production, to continue to exploit what Helen Hughes referred to as their 'culturally rich lives'.

\section{Conclusion}

Yolngu desires for facilities and services at Yilpara have been consistent since the outstation was set up. Over time, they have wanted to see a continual, incremental improvement of the facilities available to them and increasing employment opportunities. Over time, supporting government-funded institutions have been more or less able to meet their aspirations depending on government policy, available expertise and resource availability. The CIS and Rotary essentially stepped in when LHA as an organisation became chronically unable to satisfy community aspirations. Yolngu strongly supported CIS-sponsored efforts on their behalf, because they provided an opportunity to improve their housing situation and also to create a school that was more directly under their local control. There is some evidence that the rhetorical stance of the CIS/Rotary alliance was synergistic with community feelings of dissatisfaction with service provision. There was a strong belief that too many 
decisions were taken at a distance from the community and that the ways in which LHA resources were distributed did not take sufficient account of the needs of large communities. And from the beginning the homeland movement in eastern Arnhem Land emphasised local autonomy.

While the LHA inevitably had to take account of its regional responsibilities and hence could not appear to unduly favour one outstation over another, the outcomes achieved at Yilpara by the collaboration with CIS/Rotary were largely ones that the organisation supported, sometimes reluctantly, and which it facilitated, where it was able to do so. Many of the ventures were in effect collaborative, with LHA managing the budgets and providing infrastructural support - for example, in plumbing, waste disposal and electricity supply. However, LHA was becoming increasingly handicapped by government policy settings that favoured the hub communities, which in effect put the outstation movement into reverse. These policy settings had been heavily influenced by the very position that the CIS and other neoliberal theorists had long advocated, including their critique of the homelands as a factor contributing to Aboriginal disadvantage. The policies of government, which were designed to advantage the townships and take advantage of imagined mainstream job opportunities and economics of scale, did not differentiate between outstations. Detailed evaluation of the potential of different communities was not relevant to the policy agenda. So how was it that CIS/Rotary provided such strong support for Yilpara? What was it that government policy had overlooked, in this particular case, that made Yilpara an exception to the viability rules?

The answer must lie in the space between rhetoric and reality. Yilpara is among the most distant of Yirrkala outstations and has all the locational and logistical 'disadvantages' that make outstations an expensive proposition. At the same time, however, it is a community that has long shown itself to be determined to continue existing. It is a strong community that has achieved a high profile through its outstanding artists, through the 'Saltwater' collection of paintings and by successfully taking on the NT and Federal governments in the Blue Mud Bay native title claim. Yilpara has a number of leaders who have taken on national roles. Djambawa Marawili, in addition to having an international reputation as an artist, has been the long-term chairman of the Association of Northern, Kimberley and Arnhem Aboriginal Artists (ANKAAA). He is now a member of the Prime Minister's Indigenous Advisory Council. Yilpara was also instrumental in the establishment of the Yirrkala rangers. In short, Yilpara has cachet and cultural capital! It is precisely because of its high profile and the determination of its residents that Yilpara provides a suitable case for treatment and exposure. But we would argue that the factors that made it seem to be an unviable proposition are what need to be taken into account if communities like it are going to be part of the solution to Indigenous disadvantage in the future. 
Our own position is that neither governments nor CIS/Rotary have built into their analysis or vision the necessity to build a viable regional economy. Indeed, as far as recent government policy is concerned, the development of regional economies in remote Australia almost seems to have been ruled out as too difficult. The economic solution is mainstreaming and enabling Indigenous Australians to work in the resource-extraction sector. One of the many problems with that model, in eastern Arnhem Land, is that it depends on major transformations of the aspirations, motivations, mobility patterns and educational status of the Yolngu population - a social engineering project for which there is little supporting evidence for likely success (see Morphy and Morphy 2013). The CIS/ Rotary intervention at Yilpara has arguably been equally unrealistic because it has taken no account of the factors required to maintain the trajectory of the community, to enable the incremental improvements to their living standards that people desire, in the absence of regional economic development. The CIS initiatives have been based, in effect, on a massive subsidy, both financial and in terms of activating networks to which Yilpara would otherwise have had no access, unaided. Rotary has provided a resident builder/engineer at no cost, and has engineered a version of private ownership that is at least two degrees removed from the 'real' market. The developments have also been helped by the LHA, which has borne a number of hidden costs. Using community members as a volunteer labour force (subsidised by CDEP) has also facilitated the affordability of the housing.

The next stage in maintaining the trajectory of Yilpara requires addressing the matter of the regional economy, and addressing that requires a much broader focus than Yilpara itself. While mining is likely to be a long-term contributor to the NT economy, it is not likely to provide direct employment for most of the residents of the Laynhapuy homelands. It does seem that those cultural assets that have undoubtedly been one of the factors that attracted CIS/Rotary to Yilpara will continue to play an important role- for example, in the form of the craft industry, land and sea management and cultural and environmental tourism. Moreover, Indigenous knowledge and capacities are likely to provide the basis for development of new businesses - fishing being a recurrent imaginary. And nearly all of those enterprises need to be developed as part of a regional system, which requires cooperation and the sharing of resources between the various outstations and associated hub communities. It is no coincidence that Buku Larrnggay Mulka art centre has operated on the basis of a distributed production model across the homelands, nor that the recently established Lirrwi model for Indigenous tourism has developed on a hub and spokes model. Similar considerations apply in the area of infrastructure, where regional transport and services can only be supplied using a regional model of collaboration. The model of individual achievement and enterprise advocated by the CIS can only be supported if there is an element of communitarianism 
in the system. The logic of the situation also requires government to take a more active role in the development of regional economies rather than using the absence of a regional economy as a constraint on developing futures.

While Yilpara residents unquestionably desire resources that enable them to have better housing for their families and greater economic opportunities, they also wish to sustain their community as one that is integrated within a regional system. Yilpara does not see itself as a community in isolation, but as one of a set of 'suburbs', as Djambawa once put it to us, that form a distributed Djalkiripuyngu 'town'. These are the communities from which come Yilpara's wives and mothers, husbands and mothers-in-law; these are the people who come to support them in ceremony and whom they in turn support. The regional population continues to be structured by a complex web of kinship with its attendant obligations and responsibilities (F. Morphy 2010). This is something that an individualistically focused model takes no account of, and to which it attaches no significance. In short, taking a regional view of development is synergistic with Yolngu aspirations to maintain the locally grounded and interconnected, kin-based nature of their society.

\section{References}

Berndt, R. and Berndt, C. 1954. Arnhem Land, Its History and Its People. Melbourne: Cheshire.

Clarke, B. 2010. Larrpan ga Buduyurr: The Spear and the Cloud. Adelaide: Bernard Clarke Publisher.

Coombs, H. C., Dexter, B. G. and Hiatt, L. R. 1980. The outstation movement in Aboriginal Australia. AIATSIS Newsletter [NS]14: 1-8.

Dewar, M. 1989. Strange bedfellows: Europeans and Aborigines in Arnhem Land before World War II. MA thesis. University of New England, Armidale, NSW.

Dunlop, I. (dir.) 1985. We are the Landowner ... That's Why We're Here. [Film]. Sydney: Film Australia.

Egan, T. 1996. Justice All Their Own: The Caledon Bay and Woodah Island killings, 1932-1933. Melbourne: Melbourne University Press.

Flinders, M. 1814. Voyage to Terra Australis, Volume 2. London: G. \& W. Nicol.

Greenfield, B. 1954a. Killing of Aborigine Urubulu, Caledon Bay area. Unpublished report, 5 February. Northern Territory Archives, Darwin. 
Greenfield, B. 1954b. Caledon Bay natives: Further report on happenings in the Trial Bay area. Unpublished report. Northern Territory Archives, Darwin.

Hughes, H. 2007. Lands of Shame: Aboriginal and Torres Strait Islander 'Homelands' in Transition. Sydney: Centre for Independent Studies.

Laynhapuy Homelands Association Incorporated (LHAI) 2006. Laynhapuy Indigenous Protected Area: Management plan, April 2006. Unpublished draft, version 11/04/06. Yirrkala, NT: LHAI.

Morphy, F. 2002. When systems collide: The 2001 census at a Northern Territory outstation. In D. F. Martin, F. Morphy, W. G. Sanders and J. Taylor, Making Sense of the Census: Observations of the 2001 Enumeration in Remote Aboriginal Australia. CAEPR Research Monograph No. 22. Canberra: ANU E Press.

Morphy, F. (ed.) 2007. Agency, Contingency and Census Process: Observations of the 2006 Indigenous Enumeration Strategy in Remote Aboriginal Australia. CAEPR Research Monograph No. 28. Canberra: ANU E Press.

Morphy, F. 2008. Whose governance, for whose good? The Laynhapuy Homelands Association and the neo-assimilationist turn in Indigenous policy. In J. Hunt, D. Smith, S. Garling and W. Sanders (eds), Contested Governance: Culture, Power and Institutions in Indigenous Australia. CAEPR Research Monograph No. 29. Canberra: ANU E Press.

Morphy, F. 2010. (Im)mobility: Regional population structures in Aboriginal Australia. Australian Journal of Social Issues 45(3): 363-82.

Morphy, F. 2012. The Yolngu in place: Designing a population survey for northeast Arnhem Land. Agreements, Treaties and Negotiated Settlements Project Working Paper Series. Melbourne: University of Melbourne.

Morphy, F. and Morphy, H. 2013. Anthropological theory and government policy in Australia's Northern Territory: The hegemony of the 'mainstream'. American Anthropologist 115(2): 174-87.

Morphy, F. and Sanders, W. (eds) 2001. The Indigenous Welfare Economy and the CDEP Scheme. CAEPR Research Monograph No. 20. Canberra: Centre for Aboriginal Economic Policy Research.

Morphy, H. 2003. An anthropological report in relation to their claim to recognition of native title in the land and sea by the Yolngu people of Blue Mud Bay. Unpublished report prepared on behalf of the claimants at the instruction of the Northern Land Council, Darwin. 
Myers, F. R. 1986. Pintupi Country, Pintupi Self: Sentiment, Place, and Politics among Western Desert Aborigines. Washington, DC: Smithsonian Institution Press.

Peterson, N. 2005. What can pre-colonial and frontier economies tell us about engagement with the real economy? Indigenous life projects and the conditions for development. In D. Austin-Broos and G. MacDonald (eds), Culture, Economy and Governance in Aboriginal Australia. Sydney: Sydney University Press, pp. 7-18.

Shepherdson, E. 1981. Half a Century in Arnhem Land. Adelaide: H. \& E. Shepherdson.

Shergold, P. 2001. The Indigenous employment policy: A preliminary evaluation. In F. Morphy and W. Sanders (eds), The Indigenous Welfare Economy and the CDEP Scheme. CAEPR Research Monograph No. 20. Canberra: Centre for Aboriginal Economic Policy Research.

Williams, N. 1986. The Yolngu and Their Land: A System of Land Tenure and the Fight for its Recognition. Canberra: Australian Institute of Aboriginal Studies. 
This text is taken from Experiments in self-determination: Histories of the outstation movement in Australia, edited by Nicolas Peterson and Fred Myers, published 2016 by ANU Press, The Australian National University, Canberra, Australia. 